\title{
Introduction: Becoming Italian American
}

\section{Franco Pierno and Alberto Zambenedetti}

The first wave of mass immigration from Italy to the United States occurred between the second half of the nineteenth century and the end of the First World War. ${ }^{1}$ This phenomenon has been the object of numerous historical, sociological, and anthropological studies that have resulted in a fervent and very much transatlantic academic dialogue. Recent efforts by Italian scholars have appeared in translation, such as the work of Martino Marazzi and Francesco Durante, ${ }^{2}$ who have built upon the milestones laid by pioneers like Olga Peragallo and Rose Basile Green. ${ }^{3}$ As these anthologies make salient, the construction, conscious or otherwise, of the Italian-American condition was conveyed especially through the use of language: familial writings such as letters and diaries, texts produced for the immigrant community such as local newspapers, and creative works such as poems and novels written and published in the countries of immigration. As Raffaele Cocchi chronicled in 1991, the strong relationship between this new "immigrant literature" and the cultural production of the old country was explicitly celebrated in 1955 by Rodolfo Pucelli's groundbreaking Anthology of Italian and Italo-American Poetry, in which foundational works of the established Italian tradition appeared in translation alongside contemporary authors living in the diaspora, whose contributions are subdivided into "Italo-American poets" (47) and "Original English Poems of Italo-American Poets" (87). In the preface, Pucelli

\footnotetext{
${ }^{1}$ For a detailed chronology of the first major wave of immigration from Italy, see Bevilacqua, De Clementi, and Franzina. According to census data, 1880 is the last year in which Italians on American soil were counted by the thousands. From that date onward, the numbers would swell to millions: see Audenino and Tirabassi 67; Vecoli 55-88. Moreover, in her book Una Little Italy nell'Atene d'America, Martellone uses this chronology to discuss the Italian community in Boston. Consonantly, Durante's massive anthology of the literature produced by Italians in the United States is divided into two volumes: Italoamericana. Vol. 1, which covers the years 1776 to 1880; and Italoamericana. Vol. 2, 1880 to 1943.

2 See, for instance, Marazzi, Voices of Italian America; Marazzi, A occhi aperti; Durante and Viscusi, Italoamericana: The Literature of the Great Migration 1880-1943.

${ }^{3}$ See Peragallo, Italian-American Authors and Their Contributions to American Literature; Basile Green, The Italian-American Novel.
} 
predicts that "this unique anthology will be appreciated and kept in every honest and educated Italo-American home" (5; our emphasis), delineating the contours of a readership that is interested in maintaining a lively cultural exchange between both sides of the Atlantic despite the obvious linguistic barriers that arise with the hyphenation of identities. The canonization of Italian-American literature continued in Italy with Letteratura italoamericana by Filippo Fichera, whose programmatic assertion that "Dove è un italiano, ivi è Italia" (5) performed a double gesture of inclusion and definition. Underlining the powerfully tentacular nature of "country" as political entity, Fichera inscribed the diasporic into the national, while simultaneously lifting literature above citizenship, borders, boundaries, and land, which he believed were petty considerations: "in ogni luogo, nella città o nei campi, in patria o all'estero, l'italiano è sempre e soprattutto poeta" (5), he confirms, specifying that " $[\mathrm{g}] \mathrm{li}$ emigrati sono i più ardenti portatori di Poesia" (6). In his nimble essay, Fichera also underlined that the linguistic and social struggles of new immigrants were all too real for their artistic production to be folded into the larger history of Italian literature, even when a sincere desire of inclusion motivated the editorial choice. A migrant identity is perennially shifting and adjusting, transitioning not only spatially, but also temporally, sensorially, culturally, and certainly linguistically. At a time when the Italian motherland was struggling to construct its united history, millions of citizens-what Pascoli described as the "wandering," "labouring," and "rejected" Italy—experienced both the alienation of non-belonging and, at the same time, the need to recover their identity (Pascoli 171-189).

This special section of Quaderni ditalianistica wishes to contribute to the aforementioned herculean editorial and scholarly efforts by shedding some light on the effects that a number of forces (legal, political, and cultural) have had on the formation of civil and social consciences and identities in the first wave of Italian immigration in the United States. The essays by Matteo Brera and Matteo Pretelli engage with the first issues encountered by immigrants as they arrived in communities that perhaps resisted their presence, and document the cultural productions of Italian nationals in their efforts to assimilate. In "Primo Bartolini and the 'Eye-talians' of Nashville: Becoming American in the Athens of the South," Matteo Brera investigates the question of the reception of Italians in Tennessee, their settling into primarily agricultural jobs, and the creation of cultural institutions (schools, orchestras, and mutual aid societies) in support of the newly-established community. The scholar then moves to the figure of Primo 
Bartolini, who documented in his poetry the complex restructuring of his political identity and social conscience caused by life in the diaspora in a time of war. Matteo Pretelli delves deeper into one specific aspect of acculturation practices, that of the dissemination of the Italian language in immigrant communities across the United States. His essay, "Italian Americans, Education, and Italian Language: 1880-1921," focuses on the intricacies of how primary and secondary education played a key role both in the exclusion of immigrants from certain facets of American society and documents how the synergies of grassroots organizations and state-sponsored programs aimed at empowering Italians by improving literacy rates and promoting civic education among them.

The following essay discusses the rise of different kinds of institutions whose primary purpose was that of giving a voice to Italian immigrants. In "An Imagined Community of Their Own: Voices of Italian Immigrants in Il Lavoratore Italiano," Thierry Rinaldetti profiles a radical newspaper that was published weekly from 1905 to 1929 in Pittsburg, Kansas. The scholar engages with the newspaper's many purposes, which included educating the reader by spreading principles of working-class solidarity while also harnessing feelings of national affiliation to overcome regional differences. As Rinaldetti chronicles, the mission presented numerous challenges to the editors' vision of ethnic alliances and, as a result, the newspaper's identity became the terrain for the negotiation of an "imagined community" that extended beyond the publication's local readership. The final essay in this special section engages with a contemporary work of fiction: while artistic representations of early Italian immigration can be a distorting and historically unfaithful mirror, we contend that they also constitute an important element in understanding and evaluating the cultural mosaic of early "Italian Americanness." Marie-Christine Michaud's "Il Nuovomondo, Ellis Island, and Italian Immigrants: A View by Emanuele Crialese" focuses on the film's articulation of space to convey the historical realities of the immigration process. The scholar's comparative approach brings Ellis Island's documented procedures and Crialese's fictionalized account into a unique framework, highlighting the accuracy with which the film reconstructs the procedures but also exposes their dehumanizing and potentially traumatic effects.

\section{University of Toronto}




\section{Works Cited}

Audenino, Patrizia, and Maddalena Tirabassi. Migrazioni italiane. Storia e storie dall'Ancien régime a oggi. Milan: Bruno Mondadori, 2008.

Basile Green, Rose. The Italian-American Novel: A Document of the Interaction of Two Cultures. Rutherford: Farleigh Dickinson UP, 1974.

Bevilacqua, Piero, Andreina De Clementi, and Emilio Franzina, eds. Storia dell'emigrazione italiana. Rome: Donzelli, 2002.

Cocchi, Raffaele. "L'invenzione della letteratura italiana e italoamericana." Altreitalie 5 (Apr. 1991). http://www.altreitalie.it/Pubblicazioni/Rivista/ Numeri_Arretrati/N_5/Saggi/LInvenzione_Della_Letteratura_Italiana_E_ Italoamericana.kl. 17 Feb. 2017.

Durante, Francesco. Italoamericana. Vol. 1: Storia e letteratura degli italiani negli Stati Uniti 1776-1880. Milan: Mondadori, 2001. . Italoamericana. Vol. 2: Storia e letteratura degli italiani negli Stati Uniti 1880-1943. Milan: Mondadori, 2005.

Durante, Francesco, and Robert Viscusi, eds. Italoamericana: The Literature of the Great Migration 1880-1943. New York: Fordham UP, 2014.

Fichera, Filippo. Letteratura italoamericana. Milan: Editrice Convivio Letterario, 1958.

Marazzi, Martino. A occhi aperti. Letteratura dell'emigrazione e mito americano. Milan: FrancoAngeli, 2011. , ed. Voices of Italian America: A History of Early Italian American Literature with a Critical Anthology. Trans. Ann Goldstein. Madison: Farleigh Dickinson UP, 2004.

Martellone, Anna Maria. Una Little Italy nell'Atene d'America. La comunità italiana di Boston dal 1880 al 1920. Naples: Guida, 1973.

Pascoli, Giovanni. "Una sagra." In Pensieri e discorsi, 1895-1906. Bologna: Zanichelli, 1907. 171-189.

Peragallo, Olga. Italian-American Authors and Their Contributions to American Literature. New York: S.F. Vanni, 1949.

Pucelli, Rodolfo. Anthology of Italian and Italo-American Poetry. Boston: Bruce Humphries, 1955.

Vecoli, Rudolph J. "Negli Stati Uniti." In Storia dell'emigrazione italiana. Bologna: Il Mulino, 2011. 55-88. 